\title{
The Role of Social Cultural Practices in Mitigating against Premarital Pregnancies and HIVIAIDS among the Adolescents in Selected Countries of the Globe. A Literature Review
}

\section{Prof Simon M Kang'ethe}

Social Work Department, University of Fort Hare

P/B X1314 Alice, 5700, South Africa

Email: skangethe@ufh.ac.za

\section{Mr Festus Khayundi}

Department of Library and Information Sciences, University of Fort Hare

Email: fkhayundi@ufh.ac.za

\author{
Doi:10.5901/mjss.2014.v5n23p1680
}

\begin{abstract}
Succinctly, African societies are increasingly realizing the role that cultures can play in reducing, or mitigating the effects of teenage pregnancies and HIVIAIDS. The aim of this article is to explore, debate and form discourse on the role of socio-cultural factors in mitigating the effects of teenage pregnancies and HIVIAIDS. The article has utilized a review of literature methodology. The following socio-cultural aspects have been identified as factors that can have a positive effect in mitigating teenage pregnancies and HIVIAIDS: Cultural revival, renewal, reawakening and innovation; bolstering different cultures as a panacea to maintain chastity; reclaiming rites of passage; and adopting male circumcision. The article has given the following as a solution to strengthening socio-cultural factors to mitigate teenage pregnancies and HIVIAIDS: goodwill from the leaders; effectuating a cultural paradigm shift; and funding cultural activities.
\end{abstract}

Keywords: Moral decay, Moral decadence, virginity testing, cultural come back, going back to the roots, cultural paradigm shift.

\section{Problem Statement}

Perhaps the new global knowledge, wave, advocacy and a realization that the cultural practice of male circumcision constitute a pivotal niche in the therapeutic terrain of mitigating the effects of HIVIAIDS has by a huge extent challenged African researchers such as these authors to dig deeper into different facets of cultures, open debates and discourses to analyze how different ingredients and aspects of cultures can be a panacea (Kang'ethe 2013). This phenomenon has prompted a search for home grown solution to the problems of premarital pregnancies and HIVIAIDS that most societies are encountering due to increased state of moral decadence, cultural attrition and decay, as well as having societies to slide into a state of normlessness (Kang'ethe 2013, 2014a). These researchers, also posing as cultural architects investigating cultures of Africa, in particular South Africa and Kenya, challenge themselves to bring to the fore different aspects of cultures and debate on how a paradigm shift to reclaim and effectuate a cultural -come back especially among the African countries can be effectuated. They believe that since African communities had cultural benchmarks, culture mores and taboos that were working and recognized, these values can be reclaimed, repositioned and be a panacea and a solution to mitigate the effects of various undesirable practices such as premarital pregnancies, and HIVIAIDS. Such cultural dispensation could also generally bring back the cultural unifying factors that many Africans espoused and embraced some decades back. The maintenance of such cultural benchmarks, mores and taboos, these researchers believe, can be reclaimed and repositioned to take their pivotal place of giving cultures their bona fide place in checking and balancing the do's and don'ts in the contemporary societies. Discussions pertaining to how such cultures and values can be reclaimed and make a comeback to be current African societies underpin this article.

\section{Methodology}

The article has immensely benefited from the researchers' immense intuition and experience from an array of cultures, journal articles delving in cultures, books and other eclectic sources. This is to locate the place of cultures in dealing with the undesirable challenges of teenage pregnancies and HIVIAIDS in a few countries of the world. 


\section{Background and Introduction}

Although research undertakings that educated the whole world on the importance of cultures through male circumcision was championed by the western world, these researchers believe that the process mobilized and expedited the desire to relook deeply into various facts of cultures to further educate the contemporary generations of how such a culturalcomeback can be an invaluable practice that can offer a solution to many of the social illicit practices and behaviours (Kang'ethe 2013, 2014a,b). This is critical in many countries of Africa whose economies stand to be wreaked by higher prevalence of HIVIAIDS, increased state of moral decadence and decay epitomized by increased cases of teenage pregnancies, abortion, drug abuse, etc (Ramphele, 2008; Barnett \& Whiteside, 2006).

These researchers believe that many individuals from Africa who are still alive, but perhaps be at their sunset years could perhaps render evidence that yester cultural values, norms and practices have had a pivotal place to play in mitigating the effects and impacts of some of the contemporary social ills (Afolayan, 2004; Kang'ethe 2014a). Perhaps they would remember how through observation of cultural values, mores and taboos, they were able to navigate their behaviours along chastity terrain with ease (Kang'ethe 2014a). Perhaps they would also form evidence that it is the coming of the much adored civilization and modernization that threw away the African cultural terrain and made it inconsequential to follow what the white people followed (Kang'ethe 2009, 2014a). They would also perhaps agree that Africans were duped to throw away their cultures so that they can follow the cultures of their colonial masters so that the masters can be able to shepherd them with ease (Kang'ethe 2009; Afolayan 2004). These researchers believe this was a way of strengthening and curving a strong terrain of capitalism and imperialism (Kang'ethe 2009, 2013). But the masters were not forthright because the civilization that they ushered into developing countries did not have a buffer stock for bad behaviours and their perfidious ramifications thereof.

The prevalence of illicit and undesirable behaviours, both morally and ethically, and the fact that there are no policy environment which has been able to tackle the quagmire has manifested itself through teenage pregnancies, excessive drug abuse and a spate of abortions and deaths resulting from backstreet attempts to procure abortion. This is especially so in countries such as Kenya where abortion is still prohibited by law. The effects have been loathsome, detrimental, shocking and immensely painstaking. When statistics from Kenya Government indicate that over 3000 women die every year as they procure backstreet abortion, one wonders how pervasive the practice of illicit sexual affairs is (Olukoya, 2001; Kenya Human Rights Commission, 2010). This is because the statistics do not reveal those who successfully undergo abortion. This is perhaps an iceberg indicator that undeniably, sexual indulgence has been taken for granted and its permissiveness is increasing at an astronomical speed, wreaking havoc to the process of chastity as well as weakening the moral fibre that people had pride in some decades ago. With the illicit behavior being done by both the elderly and the young, it leaves no role models for the young to adore and ape. This is the societal dysfunctions of the highest order (Sheafor \& Horejsi, 2008; Segal et al, 2007).

With South African laws legally permitting sexual liberty to girls as young as 16 years, this may not augur well for their moral and sexual development (Zastrow \& Kirst-Ashman, 2013). Even though many girls at age sixteen have developed physiologically to handle sex, they may not have fully developed emotionally. Again, this is the age in which these girls are totally dependent on their parents/guardians. Also, these young people may not have fully matured to understand the future implications of such sexual engagement. This has opened room for child sexual culture and probably their sexual exploitation. This can only compromise their moral quality and chastity as future citizens. Of course with the legalization of abortion in South Africa, on one side, deaths emanating from abortion are fewer, but from moral dimension, the process is carried out without any moral implications attached to the quagmire. While issues of sexual freedom is also associated with westernization, modernization, civilization and globalization, and hugely with African countries copying the western centric cultures wholesale, it is time that Africans such as these cultural architects point out the perfidious effects and impacts of such decisions and therefore strengthen their recourse on advocacy and lobbying that can strongly effectuate for a paradigm shift that would probably and successfully bring back Afro centric cultural values that can oppose and possibly annihilate these western-centric values and norms altogether (Kang'ethe 2014a,b). It's time that Africans stand as Africans by claiming back their African ways of doing things. They should not watch back when their cultural house is on fire. The cultural architects should also take their assignments strongly to educate the Africans of how perfidious it is to let cultures be replaced with foreign cultures that they cannot manage with ease (Afolayan 2004).

If some pragmatists think this is not possible, perhaps these researchers should remind them that countries such as Japan have undergone tremendous development and yet have not lost their cultures. One does not have to cast away their cultures in order to realize development. Also development does not have to pass the western centric terrain in order for it to be development. In fact most of the Asian countries are still embracing development and leaving most if not all of 
their cultures intact (Kang'ethe 2014c);

\section{Panacea of Socio-Cultural Practices to Mitigate the Perfidious Effects of Socially Illicit Behaviour}

\subsection{Cultural Revival, Reawakening and Innovation}

Incontrovertible, African culture is full of immense social capital that should form a strong gear of cultural revival, cultural reawakening and innovation. These phenomena can be fulfilled by societies experiencing a cultural paradigm shift. This means a huge change in cultures that will involve societies changing the way they think, interpret different aspects of life, envision life and looking at life from cultural lenses. A cultural paradigm shift according to these researchers connotes a situation of achieving a cultural renewal, cultural rehabilitation, cultural reawakening, cultural innovation, and all aspects geared towards elevating the niche and value of cultures as tools of development (Kang'ethe, 2014a,b,c). This also means engaging in undoing all aspects of cultural decay and attrition to a state in which people can fully pride in strong cultures that they respect and adore, as well as recognizing different ingredients of it that are fully integrated into aspects of people's development. Therefore, cultural paradigm shift, in an African perspective means reclaiming the lost glory that the Africans used to have. Such glory includes the cultural festivals, dances and songs, bliss and happiness during various initiation rites, marriages etc (Kang'ethe \& Rhakudu, 2010; Afolayan, 2004). Since these were replaced by the western based cultures and practices, a strong cultural paradigm shift would mean expediting a wave to reverse these cultures. This includes doing the initiation ceremonies the way Africans prided in, holding and doing things in an afrocentric ways that richly grounded them in moral, social and ethical fibre of people's societies. Perhaps clarifying the panacea of effectuating a paradigm shift is critical. This is because such a shift will bring back culture mores and benchmarks that can safeguard and be checks and balances of people's behavior, especially the illicit behaviours of haphazard and ad hoc sexual engagement and involvement in behaviours that do not embrace respect to all in the society. For instance although alcohol was allowed during some ceremonies, it was not taken by all. With the culture of today, that is the western centric influenced- cultures, even children can buy their own alcohol and freely take it without anybody frowning at them. They hide under the human rights of children and immunity against child abuse (UNCRC, 1989; OAU, 1990). This is the area of permissiveness. Hopefully, a cultural paradigm shift will bring back to people the sense of morally and ethically good behaviours; recognizing cultural institutions and what they stand for, integrating aspects of their modern form of development with cultural ingredients of their societies, and starting to view and look at their world from cultural lenses. Optimistically, the cultural paradigm shift will lower cases of unwanted pregnancies and by extension lower incidences of HIVIAIDS.

\subsection{Bolstering different cultures as a panacea to maintaining chastity}

Incontrovertibly, most societies have some mechanism of controlling sexuality. This may be in the form of cultural norms, values, formal education, restrictions or social control. However in Africa and non- European countries, the controversial issue poses a strikingly gender dimension in that this control is more visible among girls than boys. It is seen as an issue of patriarchy and inequality. Proponents of African culture do not agree with this and consider those who hold this view to lack knowledge on the anthropology of the place of an African woman or mother in the African society (Afolayan, 2004; Lekoko, 2009). But we must hasten to disabuse the notion that more emphasis is placed on the control of a woman's virginity than that of a man or boy. Those males who have gone through the rites of passage will tell you that among the tutorials they receive during the liminal stages of the rites include how they should conduct themselves according to the cultural norms.

The veneration and protection of female virginity is as old as human race. It is talked of in religion and various mythologies. In Africa, female virginity is a highly regarded virtue. Most African cultures regard female virginity as a mandatory prerequisite for a stable and prosperous marriage. As a result, parents especially mothers and female relatives will ensure that their female children guard against surrendering their virginity before marriage (Kang'ethe, 2014b). Besides virginity bringing honour to the family, those who married as virgins also attracted higher dowry and other honours. For example, among the Baganda, Banyankole, and Batoro communities of Uganda, girls were closely watched so that they do not lose their virginity. Once it was ascertained that one was virgin, usually by a show of blood stained sheet after the woman spent the night with the newly married husband (through the perforation of the woman's hymen), gifts of cows or goats were sent to parents of such a girl as an appreciation and a pat on the back for their good parenthood. They were highly respected. Equally the family that also married such a virgin woman also received immense respect. Premarital pregnancies were frowned at and those girls who got pregnant outside marriage were 
thrown away from home as they brought immense shame to the family. Therefore, even today, many parents would wish their daughters not to engage in ad hoc sexual encounters for fear of getting pregnant. This is usually very dangerous during the age of adolescents' stage of identity crisis (Ocholla-Ayayo, 1993; Ericsson, 1968). Admittedly, the current danger of contracting HIVIAIDS or STIs has increased the value of virginity. Therefore, the control of virginity as a strategy in the mitigation of HIVIAIDS may serve Africa better than the formal education being advocated for by the Western countries. The trials with abstinence-only-until-marriage programs in the United States of America are not proving to be an effective solution to teenage pregnancies (Kohler, 2008).

Since the culture of virginity testing in South Africa and some neighbouring countries such as Swaziland became a norm, advocating and lobbying the practice to be brought back to the cultural shelves and be made important aspects of people's cultural agenda will not be an arduous task. And this is true because despite the South African government's weak or lack of support of this cultural practice, the current Zulu King, Goodwill Zwelitini is making strong inroads towards convincing his society that the practice can be a panacea in that it will reclaim back the lost cultural glory of chastity and therefore have societies produce well dignified women in terms of moral chastity (Kang'ethe 2014b). This would be an African solution to the much undesired states of moral decadence and HIVIAIDS. Perhaps due to the fact that Africa bears the brunt of HIVIAIDS pandemic, there is a dire and urgent need for African solutions to fighting the disease. In South Africa where the scourge of pandemic has decimated families there is need to resuscitate the cultural norms that may be instrumental in containing any further spread of the pandemic (Ramphele, 2008; Barmett \& Whiteside, 2006; Kang'ethe 2014, a,b). Perhaps both the cultural practices and the western biomedical practices can complement each other in the fight against HIVIAIDS. Therefore the resuscitation of virginity testing by King Zwelitini of the Zulu nation is an initiative to be supported instead of being condemned by those who seem to have failed to comprehend and appreciate his cultural approach to such an important problem (Kang'ethe, 2014a,b). There has been a deluge of condemnation of King Zwelitini's initiative from the obvious quarters namely the human rights movements and the western scholars. It is the argument of these writers that such a reaction to virginity testing in the Zulu nation is misplaced within the cultural relativism framework.

\subsection{Reclaiming Rites of passage}

In African societies one was born, lived, and died within the rites of passage. Among the most significant rites of passage was when a boy or girl reached puberty. Both the boy and the girl underwent prescribed rites of passage when they attained puberty. Such rites included circumcision, piercing of nose, ear, lips, teeth extraction, cutting of fingers, tattooing, etc. (Wodenmicael, 2009). The marks left by these rites denoted, among other things, age, social status, increase in sexual attraction, and woman's chastity before marriage. Those who did not undergo such rites as prescribed by their respective society did not qualify to move to the next stage and therefore culturally remained at childhood stage regardless of their chronological age and status. Married men, for example, who did not go through the required rites of passage to manhood were regarded as boys until they decided to undergo the rites of passage (Kang'ethe \& Rhakudu, 2010). Such men could not be given certain responsibilities in society. For example they were not allowed to participate in decision making for the society, and in some societies when such men died, they would be subjected to posthumous circumcision rituals before burial ceremony.

Girls or women who did not undergo the required rites of passage faced more stigma than men. They would not easily be easily married. The cultural preparation of a woman for marriage was crucial in most societies and this included the performance of all the important rites of passage before a girl was ready for marriage. Perhaps the importance of these rites was that each personality was bound by some norms and taboos as to how to behave. Age, especially was highly regarded. There are those things such as alcohol taking that one could not engage in before he was allowed by the elders. This means that the rites of passage also controlled people's behavior. Therefore these researchers cum the cultural architects would like to see African societies working towards reclaiming back the cultural rites of passage. Although western-centric cultures have infiltrated and demonized African cultures, its high time that leaders, authors and cultural architects strengthen their campaign, advocacy and lobbying for a workable cultural paradigm shift. It would be a panacea to reduce the current state of moral decadence and therefore also acts as prevention intervention against HIVIAIDS (Kang'ethe 2009, 2014,a,b).

\subsection{Male Circumcision}

In some societies both the boy and girl were subjected to circumcision as a rite of passage (Wodenmicael, 2009; Kang'ethe 2013). But there were also societies where only boys were circumcised. Female circumcision (referred to by 
the West and feminists as female genital mutilation) was and is still practiced in many parts of Africa (Wikipedia, 2014). However, the debate on the so called female genital mutilation (FMG) is not within the scope of this paper. Suffice it to say that female circumcision among African societies was and is aimed at fulfilling the cultural requirements which confers on girls attributes of cleanliness, purity, and fertility as well as at the same time reducing excessive sexual desire (Ahmadu, 2000). It is important to note that alongside the ceremonies pertaining to circumcisions, there were a lot of education that accompanied the practice, especially on how one was to maintain sexual and social behavior generally. Therefore these ceremonies of circumcision have had immense and huge social capital that shapes the lives of people. They therefore cannot be ignored and in some quarters, the proponents of these cultures need to be supported to exercise their cultural rights espoused in many countries bills of rights and the larger constitution (Barrett-Grant, Fine., Heywood. \& Strode 2001). Perhaps today the world has been treated with advocacy and lobbying, with scientific evidence that male penile circumcision gives men a $60 \%$ resilience to HIVIAIDS infection. This has seen the western world bring a lot of funding to especially Africa for the campaign on male circumcision (Peltzer et al, 2008; Kang'ethe, 2013). Although the campaign is only medical male circumcision, these authors think that traditional male circumcision would be more ideal because it will come with it the lost glory of education, respect and the afro centrism that some scholar would like to take strong roots. Such a campaign on medical male circumcision has been aggressive, more so because at the nascent stages of the campaign had it that those who underwent male circumcision were more at risk of HIVIAIDS infection than those who had not undergone the practice (Kang'ethe \& Gutsa, 2014). Therefore many African countries that have had a culture of circumcision should now take advantage to strengthen especially the traditional practice that will carry with it behavioural immense capital that will free the societies from moral decadence and also reduce chances and a etiology of HIVIAIDS

\section{The Way Forward}

\subsection{Goodwill from the leaders}

To say the least, the war to for African countries to reclaim and win back their cultural lost glory can only be possible if societies experience goodwill from leaders who should be agents of community education and dissemination to convince the society that cultures promote to bring back home grown solutions to some of the challenges the societies experience such as the escalating and burgeoning cases of teenage pregnancies and prevalence of HIVIAIDS. Perhaps the Zulu King, Goodwill Zwelitini forms such a good example by taking the bull by its horns to reclaim and resuscitate the cultural rite of virginity testing.

\subsection{Effectuating cultural paradigm shift}

Cultures and the immense capital these authors claim they have can only be realized if society agree and find sense in undergoing a cultural paradigm shift where they will have to yearn with gusto and nostalgia the different cultural ingredients that used to guide the behaviours and the lives of people some few decades ago. Observably, the realization that the new cultures of the colonizers has brought more social agonies in the lives of those who abandoned their cultures is increasingly dawning on many societies' minds with a longing to revert back to the yester cultures which had culture mares and benchmarks to steer and check the behaviours of especially the adolescents.

\subsection{Funding cultural activities}

Having the desire to effectuate a cultural paradigm shift is a heavy investment. This is because of the magnitude of damage that the cultures of the colonizers have done. It is pertinent, therefore to heavily fund the cultural education, expedite and effectuate cultural education dissemination. It is therefore also critical that governments allocate much funding to the ministries of culture if cultural information dissemination is to be effective. Perhaps the government of South needs to prove its goodwill in funding cultural activities by assenting to Zulu's King, Goodwill Zwelitini's request to fund his virginity testing campaign in the tune of R300 million ( Mthethwa, 2014).

\section{Conclusion}

Succinctly and believably, cultures can form home grown solutions to some of the horrendous and pinching challenges that continue to bedevil especially the developing countries. The fact that western campaign on HIVIAIDS is exploiting a 
cultural practice of male circumcision as one of the intervention to HIVIAIDS is full proof that cultures if deeply explored have immense social capital that can provide home grown solutions to many of the African problems such as moral decadence, teenage pregnancies and HIVIAIDS. It is therefore central that societies, as well as governments of various countries invest in analyzing and embracing various ingredients of cultures and turn them into opportunities of solution making processes. Perhaps countries need to carry out a succinct and scientific cost benefit analysis towards different aspects of cultures and determine their capacities to effectuate home grown solutions to behavior based problems.

\section{References}

Afolayan, F. ( 2004). Culture and Customs of South Africa. Westport, Connecticut: Greenwood Press

Ahmadu, Fuambai ( 2000) Rites and Wrongs: An Insider/Outsider reflects on power of excision. Available at http://www.africanholocaust.net/fgm.html

Barnett, T. \& Whiteside, A. (2006). AIDS in the Twenty-First Century. Disease and Globalization. Hampshire: Palgrave Macmillan

Barrett-Grant, K., Fine, D., Heywood, M. \& Strode, A. (eds.) (2001). HIVIAIDS and the Law: A Resource Manual (2nd edition).Johannesburg, South Africa, The AIDS Law Project and The AIDS Legal Network, University of the Witwatersrand.

Erikson EH.( 1968). Identity: Youth and Crisis. New York: Norton Publishers; 1968

Kang'ethe, S.M. (2013). The panacea and perfidy of cultural rites of circumcision in African countries: Examples from Kenya, Botswana, and South Africa. EASSRR Journal, Vol. xxix, no. 1, 107-123.

Kang'ethe S.M. ( 2014a). The panacea and perfidy of culture as a platform of behavior change with examples from Botswana and South Africa. In the press of Mediterranean Journal of Social Sciences.

S.M Kang'ethe (2014b). The need to resuscitate the cultural rite of virginity testing as a tool to strengthen the campaign against HIVIAIDS and moral decadence in South African region. Mediterranean Journal of Social Sciences. Vol .5, number 8. Page 476481

Kang'ethe S.M (2014c). Exploring efforts of integrating progressive aspects of cultures into development and purging retrogressive ones from development framework in a score of African countries. In the press of Journal of Human Ecology

Kang'ethe S.M \& Takudzwa Gutsa (2014). Evaluating the Health hazards Associated with the Cultural rite of circumcision in the contemporary South Africa and other eclectic contexts. In the press of Studies on Ethno-Medicine

Kang'ethe , S.M \& Rhakudu, M. (2010). Religious Education for Form 2. Heinemann. Gaborone Kang'ethe, S.M. (2009). Traditional healers as caregivers to HIVIAID patients. Sahara Journal. Vol. 6 (2). September, 2009. Pp.83-91.

Kenya Human Rights Commission (KHRC) (2010). Teenage pregnancy and unsafe abortion. The case of Korogocho slums. Final Report August 2010

Kohler P.K (2008). Abstinence-Only and Comprehensive Sex Education and the Initiation of sexual activity and teen Pregnancy. Journal of Adolescent Health. Vol 42 issue 4. Page 344-351

Lekoko, R.N. (2009). A Generation in jeopardy. Sexually active women in patriarchal cultural settings and HIV and AIDS In: Maundeni T, Osei Hwedie BZ, Mukaamambo E, Ntseane PG, editors. Male involvement in sexual and reproductive Health. Prevention of violence and HIVIAIDS in Botswana. Cape Town: Made Plain Communications,91-116.

Mthethwa, B (2014). Cultural village for reed dance to cost tax payers a royal $R 300$ million. Page 4 . Sunday Times.

Ocholla-Ayayo, A.B.C, Wekesa, J.M., Ottieno, J.A.M (1993). Adolescent pregnancy and its implications among ethnic groups in Kenya. International Population Conference, Montreal, Canada.

Olukoya, A.A., et al. 2001. Unsafe abortion in adolescents. Special Communication from the World Health Organisation. International Journal of Gynaecology and Obstetrics 75(2):137-147

Peltzer, K., Nqeketo, A., George, P., and K. Xola (2008). Attitudes of pre-initiates towards traditional male circumcision in the context of HIVIAIDS in the Eastern Cape, South Africa. Journal of Social Behaviour and Personality, September1, 2008.

Ramphele, M. (2008). Laying ghosts to Rest. Dilemmas of the Transformations in South Africa. Capetown: Tafelberg

Segal, E.A, Gerdes, K. E \& Steiner, S. (2007). An introduction to the profession of Social Work. Becoming a change agent. Second edition. Thomson. Brooks/Cole.

Sheafor, B. W. \& Horejsi, C. R. ( 2008). Techniques and guidelines for Social Work Practice. Allyn \& Bacon. Boston, London, Sydney \&Toronto.

UNCRC. Conventions on the Rights of Children. Adopted by the General Assembly of the United Nations on 20 th November, 1989. Organization of African Unity. African Charter on the rights and welfareof the child. OAU.doc. CAB/LEG/24.9/49.1990.

Wodenmicael, G. (2009). Female genital cutting in contemporary Eriteria: Determinants, future prospects, and strategies for eradication. EASSRR, Vol XXV. № 2. June 2009.

Zastrow, C.H \& Kirst-Ashman, K.K.(2013). Understanding Human behavior and the social environment. Brooks/Cole. United Kingdom 